\title{
Earnings management under a global magnifier
}

\author{
Vladislav Krastev ${ }^{1}$, Pavol Durana ${ }^{2, *}$, and Katarina Valaskova ${ }^{2}$ \\ ${ }^{1}$ South-West University, Department of Economics, 2746 Blagoevgrad, Bulgaria \\ ${ }^{2}$ University of Zilina, Faculty of Operation and Economics of Transport and Communications, \\ Department of Economics, Univerzitna 1, 01026 Zilina, Slovakia
}

\begin{abstract}
.
Research background: Legal earnings manipulation is current hot topic, which is evidenced by a significant number of academic articles from the countries of developed markets. But this issue has been still the research gap for the emerging countries. Slovakia and Bulgaria are emerging counties with the similar economic and political history. The existence of the purposeful earnings management is confirmed in both countries. Therefore, the enterprises from these countries are selected to the common comparison.

Purpose of the article: The main purpose and the set target of delivered examination is to disclose significant conformity or discrepancy in the dimension of the legal managers' earnings modification in the Slovakian and Bulgarian enterprises.

Methods: The provided financial modelling used 1,089 Slovak enterprises and 1,421 Bulgarian enterprises. Two parametric tests were computed for this study. Fisher's F-test to detect the ratio between the variances of the populations, and t-test for two independent samples to test provided hypothesis of the article.

Findings \& Value added: The paper aimed at the earnings before interest, taxes (EBIT) in two emerging countries under a global magnifier. It was detected that the dimension of financial managers' earnings manipulations in the Slovakian and Bulgarian enterprises is not significantly different. The similar nature of the approach of the management to the earnings manipulation was identified.
\end{abstract}

Keywords: business finance; earnings management; EBIT; emerging countries, globalization

JEL Classification: $M 48 ; G 30 ; F 60$

*Corresponding author: pavol.durana@fpedas.uniza.sk 


\section{Introduction}

Trying to present the entity "in the better light" leads the management of many enterprises to the improvement of results by earnings management [1]. This phenomenon of legal earnings modification is an increasingly hot topic, which is a necessary part of the rational behavior of the enterprise that aims to survive in a challenging competitive environment in the long term [2] as well as in the areas of global financial accounting, global financial risk and global financial modelling [3]. This worldwide used tool is known in emerging countries, but the number of research studies from these countries is lax comparing to the developed ones. Slovakia and Bulgaria are included in the group of emerging countries. These countries are very close with similar anamnesis of macroeconomic development and political genesis (Soviet-controlled countries). The quantitative analysis of [3] confirms significant existence of legal earnings manipulations in Slovak and Bulgarian enterprises as well. The managerial activities are purposeful, which is proven by the existence of no stationarity in the time series of earnings before interest and taxes and a clear occurrence of the unit root. The way of reporting information and related earnings quality is an integral part of earnings management and it is in the competencies of the managers [4].

Therefore, the main objective of delivered investigation is to disclose significant conformity or discrepancy in the dimension of managers' earnings manipulations in the Slovakian and Bulgarian enterprises.

The manuscript is structured as follows. In the introduction, the cause of the paper and the significance of the topic of earnings management are provided. Then, bibliometric analysis of the earnings management is made, supported by short literature review. Thirdly, the nature of the observations and the explanations of used methods are shown to gain the selected aim. Followed by the description of set hypothesis. Next chapter contains the results of Fisher's F-test and t-test for two independent samples. Discussion involves limitations of the study a potential focus of the researches. In addition, this part includes the comparison of the recent investigations of analyzed area from emerging countries.

\section{Theoretical background}

\subsection{Bibliometric analysis}

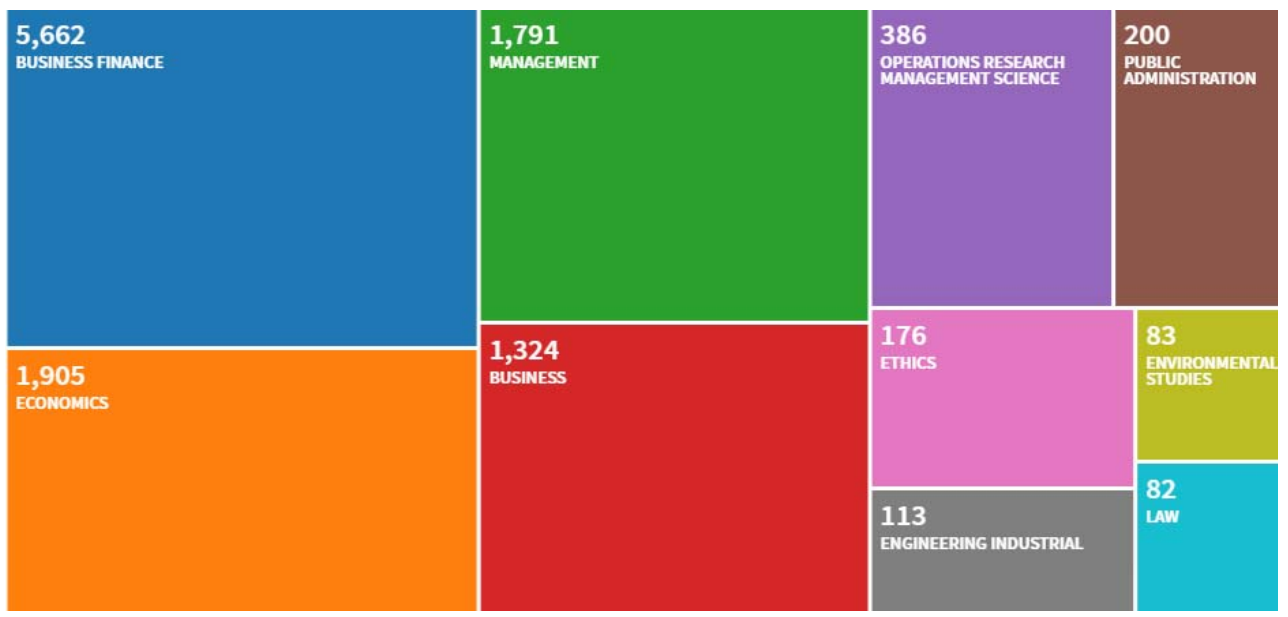

Fig. 1. Number of publications concerned with earnings management in Web of Science Categories. Source: own research based on Web of Science Core Collection. 
Earnings management means a global phenomenon that has attracted the attention of academic researchers for a long time, as evidenced by a significant number of expert papers that is not only mentioned bellow. According to Figure 1, earnings management belongs to the crucial issue of business finance. More than five thousand theoretical and empirical contributions have been published in this area. Economics, management and business are also core categories in which earnings management is often dealt. Finally, the categories of operations research management science, public administration, ethics, engineering industrial, environmental studies, and law pay attention to earnings management. These ten categories discuss the areas of the earnings management most frequently based on Web of Science.

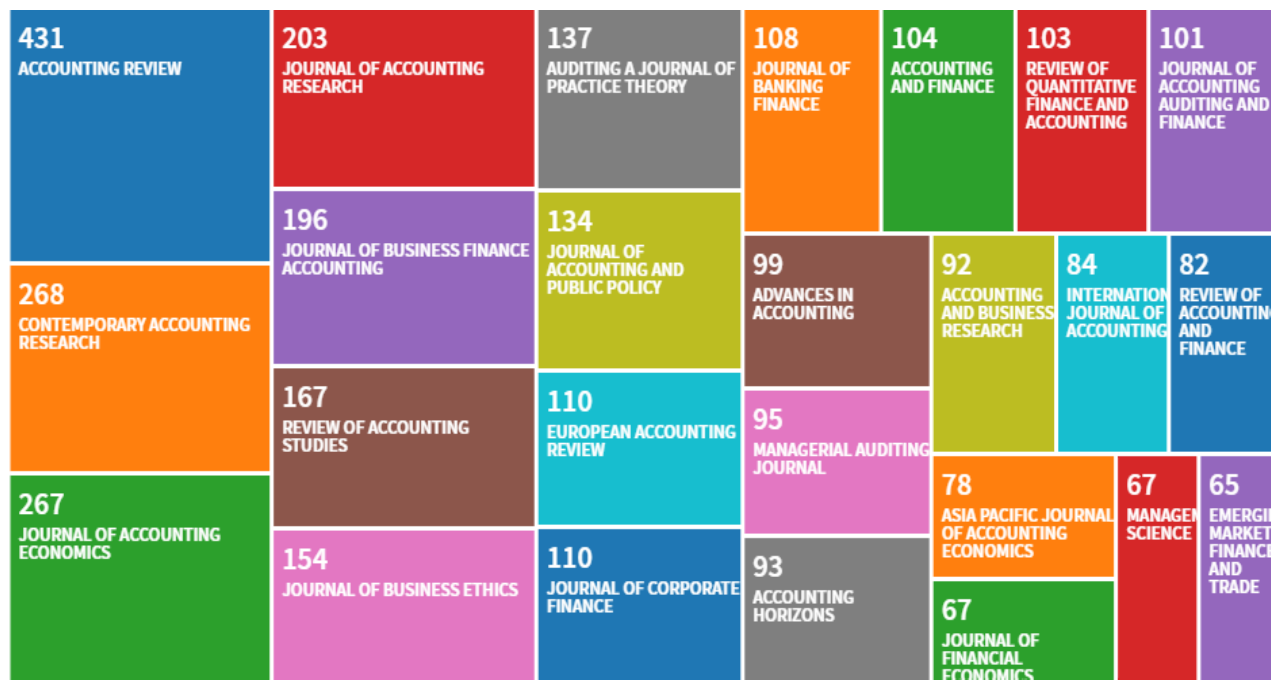

Fig. 2. Number of publications concerned with earnings management in Web of Science according to journals.

Source: own research based on Web of Science Core Collection.

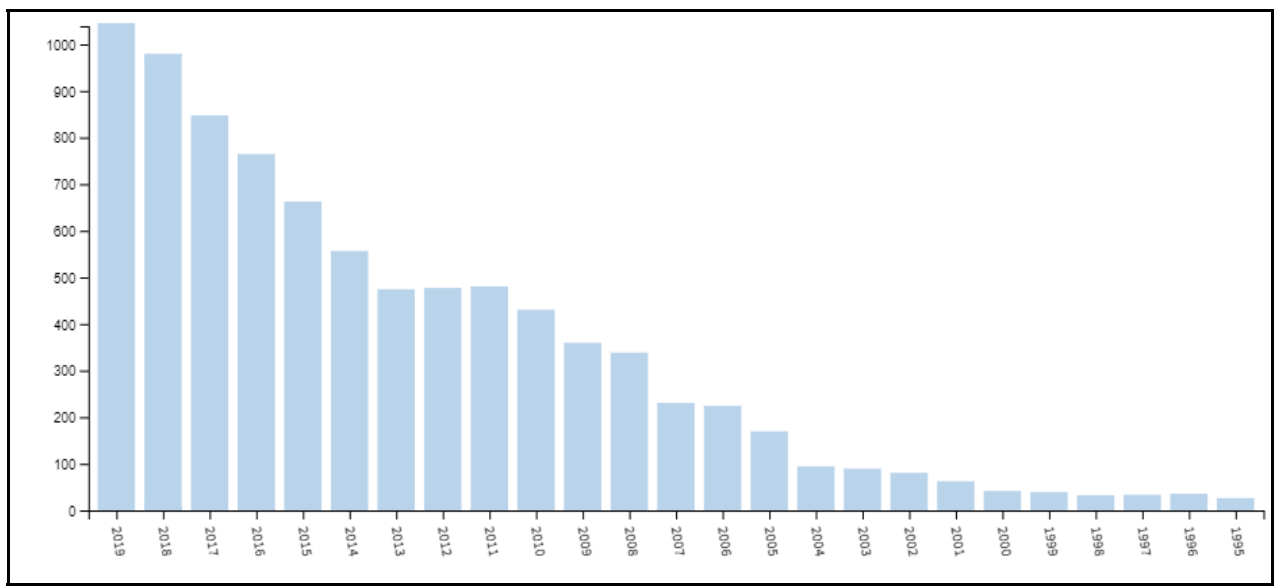

Fig. 3. The development of publications concerned with earnings management in Web of Science in time.

Source: own research based on Web of Science Core Collection.

The research importance of analyzed topic is confirmed by the number of articles published in impacted scientific journals from the Web of Science Core Collection (Figure 
2). The topic of earnings management is a research area discussed with a positively rising trend with a significant annual increase in the number of publications concerned with earnings management in the last seven-year period. The fact is demonstrated in Figure 3.

Figure 4 shows the number of publications concerned with earnings management according to the countries. From all the countries, earnings management is the most discussed topic in the USA. Almost five thousand research papers have their origins in this country. We may highlight that developed European countries, such as England, Spain, Germany, Italy, Netherland, Belgium, Greece, or Scotland, focus on earnings management. However, emerging countries, for instance Slovakia and Bulgaria together, have less than ten research papers devoted to this issue. The presented fact also verifies our detected scientific gap because minimal academic attention is paid to this chosen significant research area in these countries.

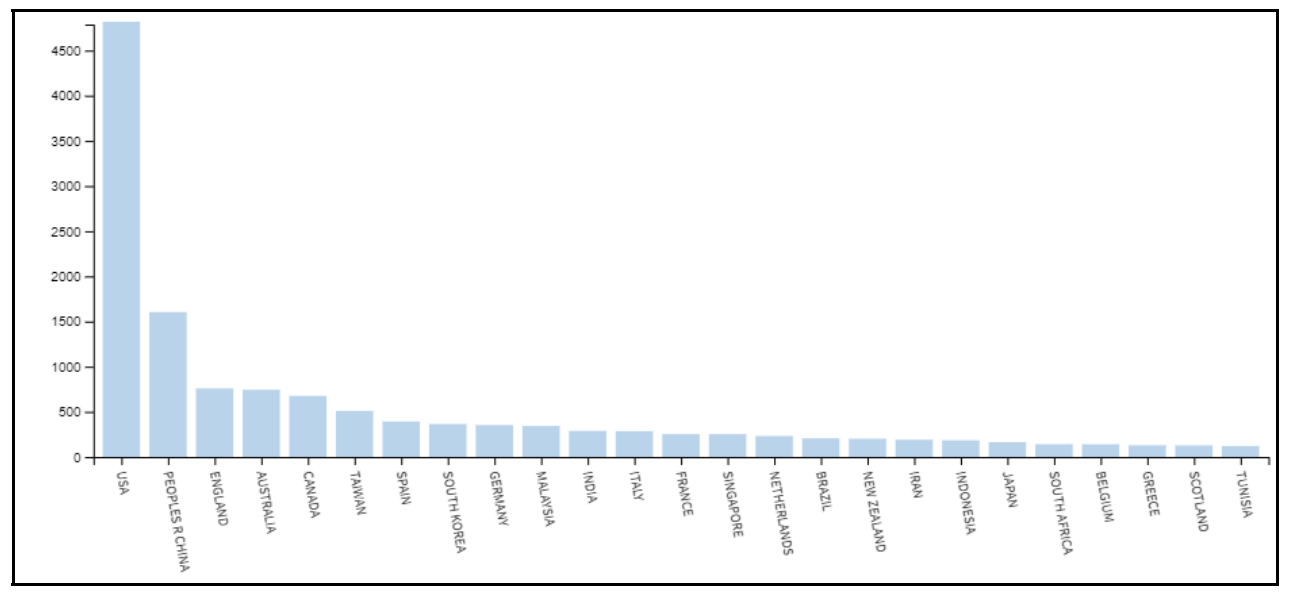

Fig. 4. Number of publications concerned with earnings management in Web of Science. Source: own research based on Web of Science Core Collection.

\subsection{Literature review}

This part includes the review of the relevant studies to this issue. [5] examine whether enterprises from countries presenting higher levels of corruption are more likely to have higher levels of earnings management than their counterparts from countries with lower levels of corruption, and how this relationship compares between emerging and developed economies. [6] find out the dependence between Nordic corporate governance practices and earnings management. [7] study the effects of financing policy and countries' institutionalfinancial characteristics on earnings management practices in Latin American companies. [8] aim to understand how reputation, financial distress and financial performance influence Shariah-compliant companies into engaging earnings management behaviour. [9] analyze various points of view of the role of the Bulgarian leader and his/her efficiency in the accomplishment of earnings objectives of the enterprises in the Bulgarian and world reality and guidelines for its sustainability and successful application in contemporary economics. [10] investigate the mechanism through which corporate credit ratings affect dividend payments by decomposing the mean difference of dividends into a part that is explained by the determinants of dividends and a residual part that is contributed by the pure credit group effect. [11] theoretically clarify the problems related to the business environment, and to assess its condition in Bulgaria and its impact on the earnings management. [12] demonstrate that capital increases taking place in the Spanish banking system for almost 
half a century (1971-2017) led to an increase in both the solvency and the profitability of the system, taking into account the changing situation in the Spanish banking environment in this period. [13] indicate the influence of audit committee effectiveness and audit quality (auditor size) on earnings management by firms listed on the Ghana Stock Exchange. [14] determine governmental turnover and its impact on the sustainability of public policy in the Palestinian context. [15] identify the determinants of financial reporting quality, which is a very complex issue in the manufacturing industry and a significant contributor to the finance of the enterprise.

\section{Materials and methods}

This investigation is an addition to the study of [3]. The observations of earnings before interest and taxes (EBIT) of 1,347 Slovak enterprises and 1,839 Bulgarian enterprises were used. The observations were originally extracted from the Amadeus database (provided by Moody' s analytics company Bureau van Dijk) mapping the nine-year period (2010-2018). The variable EBIT is selected to eliminate different tax and interest policies of these countries. The enterprises have to meet three set criteria: the value of total assets at the minimal level of $3,000,000 €$; the value of total sales at the minimal level of 2,000,000 $€$; the value of net income at least $100,000 €$ [3]. The Dixon test was run to identify the existence of outlying observations in the samples of the enterprises. The selected test confirmed the occurrence of outliers in all monitored years in both samples. The ultimate sample after eliminating of the inconsistent observations contained 1,089 Slovak enterprises and 1,421 Bulgarian enterprises. The next step in pre-processing of the data was to calculate the average values of EBIT per year that followed normal distribution based on run Jarque-Bera test [3]. The Figure 1 and Table 5 depict box plots made from annual EBIT and brief summary statistics of analyzed Slovak and Bulgarian enterprises. This descriptive analysis is recommended by [16] to provide comprehensive basis of the profit of the enterprises.

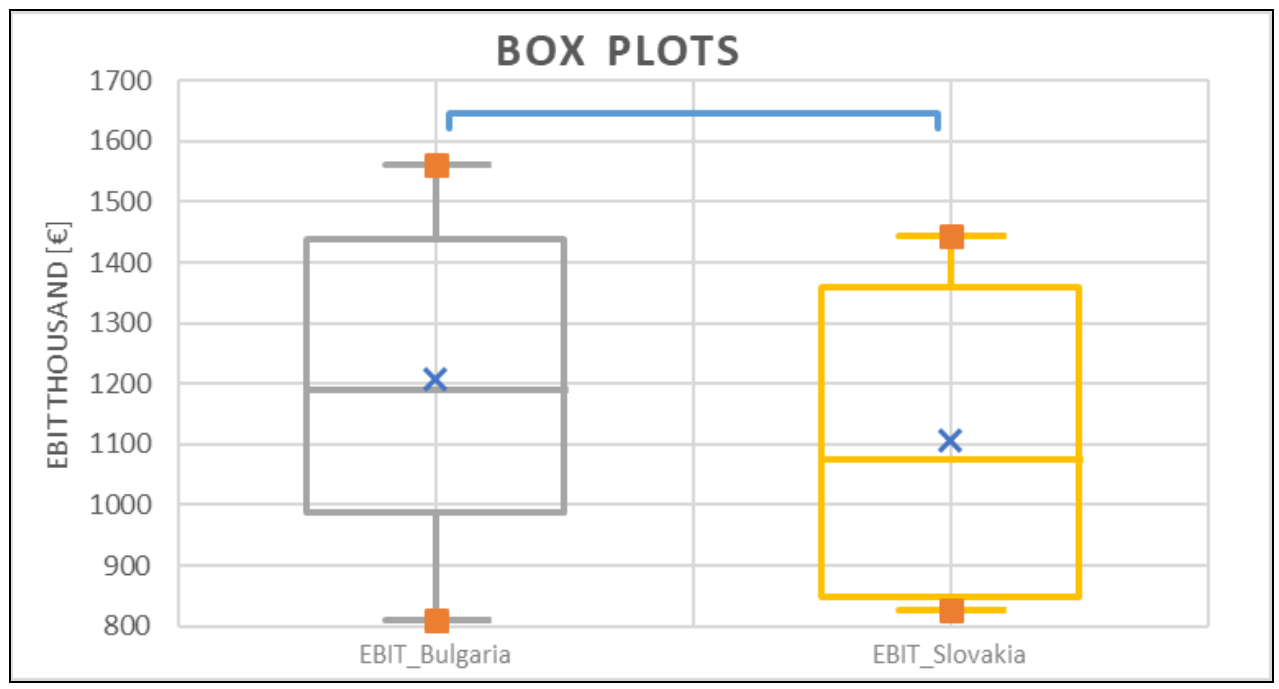

Fig. 5. Box plots of EBIT of Slovak and Bulgarian enterprises.

Source: own research. 
Table 1. Summary statistics. Source: own research.

\begin{tabular}{|c|c|c|c|c|}
\hline Country & Minimum & Maximum & Mean & Standard deviation \\
\hline Slovakia & 809.544 & 1561.801 & 1207.374 & 285.334 \\
\hline Bulgaria & 826.304 & 1444.950 & 1107.130 & 268.330 \\
\hline
\end{tabular}

The process of generalizing knowledge, for example, by transferring the conclusions from the selection to the whole country, is called an inductive method [17]. Inductive method of testing hypotheses is used to disclose significant conformity or discrepancy in the dimension of managers' earnings manipulations in the Slovak and Bulgarian enterprises. This methodological step generates 'generalizing knowledge' from used observations of EBIT in selected two countries (two independent populations). The analysis allows us to formulate the following hypothesis which is tested at the significance level alpha 0.05:

$H_{0}$ : The difference between the means of EBIT of Bulgarian and Slovakian enterprises is equal to 0 .

$H_{A}$ : The difference between the means of EBIT of Bulgarian and Slovakian enterprises is greater than 0 .

If one cannot reject the null hypothesis that financial data of EBIT of analysed emerging countries follow the normal distribution it is possible to run the parametric tests to test presented hypothesis. Following tests are used:

1. Fisher's F-test to detect the ratio between the variances of the populations,

2. t-test for two independent samples to test presented hypothesis of the article.

\section{Results}

Firstly, Fisher's F-test is computed to indicate the ratio between the variances of the samples of EBIT.

$H_{0}$ : The ratio between the variances is equal to 1 .

$H_{1}$ : The ratio between the variances is different from 1.

Table 2. Fisher's F-test (Two-tailed test). Source: own research.

\begin{tabular}{|c|c|}
\hline Ratio & 1.131 \\
\hline F (Observed value) & 1.131 \\
\hline$|\mathbf{F}|$ (Critical value) & 4.433 \\
\hline DF1 & 8 \\
\hline DF2 & 8 \\
\hline p-value (Two-tailed) & 0.866 \\
\hline alpha & 0.05 \\
\hline
\end{tabular}

As the computed p-value is lower than the significance level alpha, one cannot reject the null hypothesis based on the Table 2. The ratio between the variances of populations of EBIT of Bulgarian and Slovakian enterprises is equal to 1 . This fact is confirmed by Figure 6. 


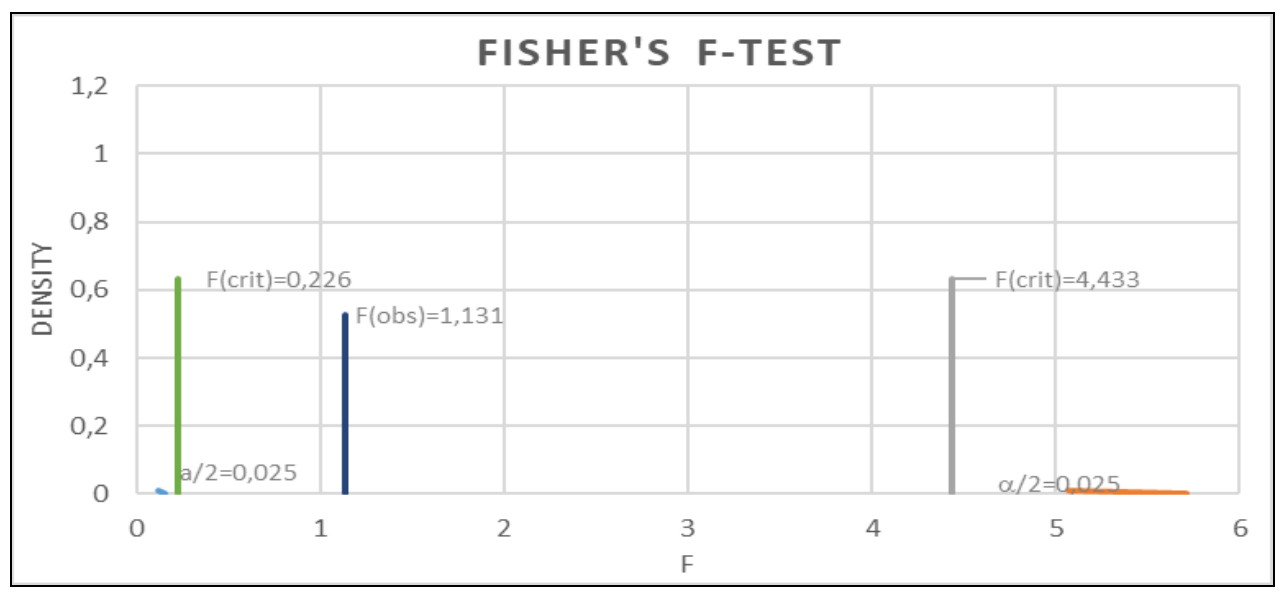

Fig. 6. Fisher's F-test.

Source: own research.

Secondly, it may be calculated two-sample t-tests assuming equal variance.

$H_{0}$ : The difference between the means of EBIT of Bulgarian and Slovakian enterprises is equal to 0. The dimension of managers' earnings manipulations in the Slovakian and Bulgarian enterprises is not significantly different.

$H_{A}$ : The difference between the means of EBIT of Bulgarian and Slovakian enterprises is greater than 0. The dimension of managers' earnings manipulations in the Slovakian and Bulgarian enterprises is significantly different.

Table 3. t-test for two independent samples (Upper-tailed test). Source: own research.

\begin{tabular}{|c|c|}
\hline Difference & 100.244 \\
\hline $\mathbf{t}$ (Observed value) & 0.768 \\
\hline $\mathbf{t}$ (Critical value) & 1.746 \\
\hline DF & 16 \\
\hline p-value (one-tailed) & 0.227 \\
\hline alpha & 0.05 \\
\hline
\end{tabular}

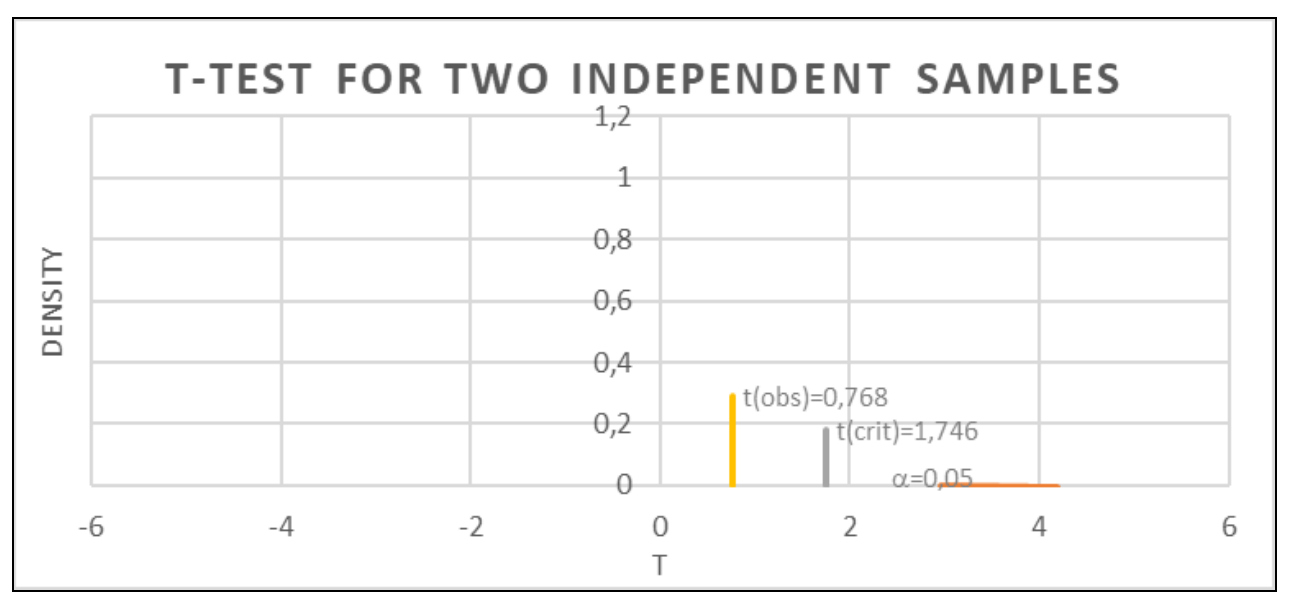

Fig. 7. t-test for two independent samples assuming equal variance.

Source: own research. 
As the computed p-value is greater than the significance level alpha, one cannot reject the null hypothesis, based on the Table 3. This fact is confirmed by Figure 7. The investigation focused on earnings management discloses significant conformity under a global magnifier. The dimension of managers' earnings manipulations in the Slovakian and Bulgarian enterprises is not significantly different.

\section{Discussion}

The results of presented issue are discussed to the incentives of the academics from the emerging countries in this part. [18] perform the analyses and make the estimates regarding the harnessing of artificial intelligence in the audit, tax, and the management accounting domains. The collected data are tested against the research model by using structural equation modelling. [19] also perform the analyses and make the estimates regarding how Industry 4.0 is delivering revenue, cost and efficiency gains. [20,21] evaluate the efficiency of non-profit organizations that are young subjects of economic relations. [20] use data envelopment analysis to determine the efficiency. [21] note that a close look at the nonprofit organizations confirms the view that in practice, not-for-profit organizations are subject to management tools that are effective in the commercial sphere, although the objectives of their functioning are fundamentally opposite. The study realized by [22] assesses the effectiveness of quantified financial flows related to the cost by the analysis by cost-benefit analysis. The investigation emphasizes the fact that the reduced risks should be acceptable in terms both of a community-wide but also of an operator's point of view and [23] add that the reduction of the risk is connected with fulfilling a number of technical and operational conditions and requirements. [24] detect two basic techniques of earnings management. The window dressing technique is less demanding and can be used by less proficient people to improve the company's position, especially in terms of profitability. The second technique of off-balance sheet financing is much more demanding in terms of knowledge and expertise and is rarely detectable in practice.

The basic limitation of the study is using parametric tests that are not originally created and constructed for time series modelling. The second limitation is affected by calculating only short time series of financial data. The third one is caused by selective choice of the countries.

The potential focus of the researches is determined by the study of [25]. The authors suggest and recommend the possibilities of the development of investigations for different economic sectors (not in general) and different countries.

This research was financially supported by the Ministry of Education, Science, Research and Sport of the Slovak Republic and Slovak Academy of Sciences VEGA 1/0121/20: Research of transfer pricing system as a tool to measure the performance of national and multinational companies in the context of earnings management in conditions of the Slovak Republic and V4 countries.

\section{References}

1. Kovalova, E., Frajtova Michalikova, K. (2020). The creative accounting in determining the bankruptcy of business corporation. SHS Web of Conferences, 74, 01017.

2. Balcerzak, A. P., Kliestik, T., Streimikiene, D., Smrcka, L. (2017). Non-parametric approach to measuring the efficiency of banking sectors in European Union Countries. Acta Polytechnica Hungarica, 14(7), 51-70.

3. Durana, P., Valaskova, K., Chlebikova, D., Krastev, V., Atanasova, I. (2020). Heads and tails of earnings management: quantitative analysis in emerging countries. Risks, 8(2), 57. 
4. Svabova, L., Kramarova, K., Chutka, J., Strakova, L. (2020). Detecting earnings manipulation and fraudulent financial reporting in Slovakia. Oeconomia Copernicana, 11(3), 485-508.

5. Lourenco, I. C., Rathke, A., Santana, V., Branco, M. C. (2018). Corruption and earnings management in developed and emerging countries. Corporate Governance: The International Journal of Business in Society, 18(1), 35-51.

6. Kjærland, F., Haugdal, A. T., Søndergaard, A., Vågslid, A. (2020). Corporate governance and earnings management in a Nordic perspective: evidence from the Oslo Stock Exchange. Journal of Risk and Financial Management, 13(11), 256.

7. Mendoza, J. A. M., Yelpo, S. M. S., Ramos, C. L. V., Fuentealba, C. L. D. (2020). Effects of capital structure and institutional-financial characteristics on earnings management practices. International Journal of Emerging Markets.

8. Sabrun, I. M., Muhamad, R., Yusoff, H., Darus, F. (2018). Do Shariah-compliant companies engage lesser earnings management behaviour? .AJBA, 11(1), 1-36.

9. Usheva, M., Danchova, M. V. (2019). Contemporary leadership in Bulgarian economics. Revista Inclusiones, 6, 77-89.

10. Nguyen, A. H., Duong, C. T. (2020). Provincial governance quality and earnings management: empirical evidence from Vietnam. The Journal of Asian Finance, Economics, and Business, 7(2), 43-52.

11. Madgerova, R., Kyurova, V., Atanasova, A., Koyundzhiyska-Davidkova, B. (2019). Study of the business environment for the development of youth entrepreneurship in Bulgaria. Theoretical and practical aspects. Revista Inclusiones, 6, 90-104.

12. Fruet-Cardozo, J. V., Millan, J. R., y Ocerin, J. M. C., Perez-Galvez, J. C. (2019). Impact of capital increase on solvency and profitability of Spanish deposit banks. Economics \& Sociology, 12(3), 273-290.

13. Agyei-Mensah, B. K., Yeboah, M. (2019). Effective audit committee, audit quality and earnings management: evidence from the Ghana Stock Exchange. International Journal of Managerial and Financial Accounting, 11(2), 93-112.

14. Alaysa, J., Musa, H. (2020). The turnover of Palestinian governments and its selected impacts on the sustainability of public policy. NISPAcee Journal of Public Administration and Policy, 13(1), 9-34.

15. Irwandi, S. A., Pamungkas, I. D. (2020). Determinants of financial reporting quality: Evidence from Indonesia. Journal of International Studies, 13(2), 25-33.

16. Cugova, A., Cug, J., Lazaroiu, G. (2019). Descriptive analysis of company's profit as a basis for earnings management. In K. S. Soliman (Ed), 33rd International-BusinessInformation-Management-Association (IBIMA) Conference (pp. 5629-5638). Granada: IBIMA.

17. Kot, S., Rajiani, I. (2020). Testing and identifying variable dependency through the fisher exact test in central Europe enterprises. Ekonomicko-manazerske spektrum, 14(1), 10-18.

18. Ionescu, L. (2020). Robotic process automation, deep learning, and natural language processing in algorithmic data-driven accounting information systems. Analysis and Metaphysics, 19, 59-65.

19. Graessley, S., Suler, P., Kliestik, T., Kicova, E. (2019). Industrial big data analytics for cognitive internet of things: wireless sensor networks, smart computing algorithms, and machine learning techniques. Analysis and Metaphysics, 18, 23-29. 
20. Vagner, L., Zadnanova, S. (2019). Non-profit organizations and their possibilities of measuring efficiency. In M. L. Simic, B. Crnkovic (Eds), 8th International Scientific Symposium Economy of Eastern Croatia Vision and Growth (pp. 1159-1165). Croatia: Josip Juraj Strossmayer University of Osijek.

21. Shemyatikhina, L., Shipitsyna, K., Usheva, M. (2020). Marketing management of a non-profit organization. Ekonomicko-manazerske spektrum, 14(1), 19-29.

22. Kampova, K., Makka, K., Zvarikova, K. (2020). Cost benefit analysis within organization security management. SHS Web of Conferences, 74, 01010.

23. Makka, K., Kampova, K., Boros, M. (2019). Workplace training in the fuels distribution company. In L. Goméz Chova, A. Lopez Martine \& I. Candel Torres (Eds), 13th International Technology, Education and Development Conference (INTED2019) (pp. 3990-3995). Valencia: IATED Academy.

24. Cugova, A., Cug, J. (2020). Motivation for the use of creative accounting techniques in the conditions of the globalized business environment. SHS Web of Conferences, 74, 01004.

25. Kampova, K., Makka, K., Zvakova, Z., Pellowski, W. (2018). The eSEC portal as a tool for the concept of corporate social responsibility. In F. Jakab (Ed.), 16th International Conference on Emerging Elearning Technologies and Appplications (pp. 261-266). USA: IEEE. 